\title{
RELATIONSHIPS BETWEEN FAT DEPOTS ÄND BODY CONDITION SCORE OR TAIL FATNESS IN THE RASA ARAGONESA BREED
}

\author{
A. Teixeira $\dagger$, R. Delfa and F. Colomer-Rocher \\ Department of Animal Production, Servicio de Investigación Agraria de la Diputación \\ General de Aragón, Apartado 727 Zaragoza, Spain
}

\begin{abstract}
The relationships between body fat depots and body condition score (BCS) were determined in 52 adult Rasa Aragonesa ewes aged 10 (s.d. 2) years and ranging in BCS from 1.5 to 4.5 . BCS of each ewe was assessed by three people, the repeatability within individuals being $90 \%$ and between individuais $80 \%$. The ewes were weighed before slaughter. After slaughter the omental, mesenteric, kidncy and pelvic fat were separated and weighed. The fat of the left side of the carcass was separated into subcutaneous and intermuscular depots. The relationship between live weight and BCS was semilogarithmic and those between fat depots and BCS were logarithmic. Regression analysis was also used to describe the relationships between the various fat depots and BCS or live weight. Of the variation in total fat weight. proportionately 0.90 was accounted for by variations in BCS, while 0.84 was accounted for by variations in live weight. For individual fat depots proportionately 0.86 to 0.90 of the variation was accounted for by variation in BCS and 0.69 to 0.79 by variation in live weight. BCS was a better predictor than live weight of the weight of both total body fat and the individual fat depots.

A curvilinear regression between BCS and live weight showed that the increases in live weight for a unit change in BCS was 7, 10,12 and $16 \mathrm{~kg}$ for each one point increase in BCS from 1 to 5 respectively.

The tail fat depot (tail fatness score) was assessed in the same ewes by score on a three-point scale. Of the variation in the weight of individual fat depots, proportionately 0.79 to 0.86 was accounted for by variation in tail fatness score. Thus the tail fatness score could be used as an additional method of assessing body condition in the Aragonesa breed.
\end{abstract}

\section{INTRODUCTION}

BODY condition was defined by Murray (1919) as 'the ratio of the amount of fat to the amount of non-fatty matter in the body of the living animal'. Subjective estimates of body condition are used widely by farmers and technicians for describing body condition under practical production conditions. system for describing body condition in sheep, based on five-point scale assessed by palpation of the lumbar region was devised by Jefferies (1961).

Russel, Doney and Gunn (1969), using an adaptation of Jefferies' system in 30 Scottish Blackface ewes, showed that body condition score (BCS) was related to the proportion of chemical fat in the body. The system has

\footnotetext{
$\dagger$ Present address: Instituto Politecnico de Braganca
} Apartado 38. Braganca, Portugal. proved useful in quantifying relationships between body condition and certain reproduction characteristics (Gunn, Doney and Russel, 1969 and 1972; Gunn, Doney and Smith, 1979). This method assesses mainly subcutaneous fat cover with some indication of muscle thickness which may partially reflect changes in intermuscular fat. The variation in partitioning of fat among the main adipose tissue depots and the changes in various fat depots for a unit change in body condition could affect the relationships between BCS and body fat.

The principal objective of the present study was to determine the relationships between BCS and both total body fat and the individual fat depots (omental, mesenteric, kidney and pelvic fat, subcutaneous and intermuscular). An assessment was also made of palpation of tissues around the tail. This 
technique is used commonly by sheep producers in many. countries to estimate body condition.

\section{MATERIAL AND METHODS}

The body conditions of 52 adult Rasa Aragonesa ewes (age 10 (s.d. 2) years), in 13 groups of four were scored using the Russel technique which employs a 1 to 5 score range and intervals of 0.25 units. The BCS of each ewe was assessed to the nearest $0 \cdot 25$ score by three experienced people.

At the same time the tail fat deposition (tail fatness score) was assessed and scored to the nearest $0 \cdot 50$, by three people on a threepoint scale defined as:

grade 1 - all the tail vertebrae can be felt easily; no fat cover;

grade $2-$ spinous and transverse processes of tail vertebrae are prominent; thin fat cover;

grade 3 - spinous and transverse processes of tail vertebrae cannot be felt and have a thick fat cover.

Before slaughter, the ewes were weighed, without being fasted overnight. After slaughter, the contents were removed from the digestive tract, weighed and subtracted from body weight to obtain empty body mass. The omental, mesenteric, kidney and pelvic fat were removed and weighed separately. The carcasses were halved carefully and the fat in the left side of the carcass was separated into subcutaneous and intermuscular fat component. The total body fat was calculated as the sum of all these fat depots.

The relationships between the various fat depots and BCS and live weight were analysed using regression analyses, in the sequence: untransformed variables; dependent variables on logarithmic scale and independent variables on logarithmic scale. Regression analyses between fat depots and tail fatness score were also carried out.

Using total fat weight as the independent variate, relative growth coefficients (b) for each fat depot was calculated from the equation of Huxley (1932):

$$
\left.\log _{10} \text { (fat depot }\right)=a+b \log _{10} \text { (total fat). }
$$

The significance of differences between all allometric coefficients $(b)$ were determined using the confidence intervals for each one (Steel and Torrie, 1980).

\section{RESULTS AND DISCUSSION}

The means and s.d.s of all characteristics measured, grouped according to condition score, are shown in Tables 1 and 2. All characteristics showed substantial variation within condition score categories.

The repeatability of BCS was $90 \%$ within individuals and $80 \%$ between individuals.

The regression relationships between live weight and BCS are shown in Table 3. The linear equation 1 , shows the relationship between live weight and BCS. The change in live weight per unit change in condition score

TABLE 1

Body weight, empty body weight and fat depots grouped according to body condition score $(B C S) \dagger$

\begin{tabular}{|c|c|c|c|c|c|c|c|c|c|c|}
\hline \multirow[b]{2}{*}{$\mathrm{BCS}$ group } & \multicolumn{2}{|c|}{$\begin{array}{l}\text { Body weight } \\
(\mathrm{kg})\end{array}$} & \multicolumn{2}{|c|}{$\begin{array}{l}\text { Empty body } \\
\text { weight }(\mathrm{kg})\end{array}$} & \multicolumn{2}{|c|}{$\begin{array}{l}\text { Omental fat } \\
(\mathrm{g})\end{array}$} & \multicolumn{2}{|c|}{$\begin{array}{l}\text { Mesenteric } \\
\text { fat }(\mathrm{g})\end{array}$} & \multicolumn{2}{|c|}{$\begin{array}{l}\text { Kidney and } \\
\text { pe!vic fat } \\
\text { (g) }\end{array}$} \\
\hline & Mean & s.d. & Mean & s.d. & Mean & s.d. & Mean & s.d. & Mean & s.d. \\
\hline 1.5 to $1.75($ no. $=8)$ & $32 \cdot 9^{a}$ & $4 \cdot 6$ & $25 \cdot 3^{\mathrm{a}}$ & $3 \cdot 7$ & $170^{\circ}$ & $112 \cdot 0$ & $280^{\circ}$ & 189.5 & $108^{a}$ & $71 \cdot 1$ \\
\hline 2.0 to $2.25($ no. $=8)$ & $35 \cdot 3^{\text {a }}$ & $4 \cdot 3$ & 27 & 2.9 & $264^{-1}$ & 101.8 & $417^{\text {ath }}$ & 20. & $267^{\mathrm{n}}$ & $109 \cdot 6$ \\
\hline 2.5 to 2.75 (no. $=8$ ) & $42 \cdot 4^{\mathrm{b}}$ & $4 \cdot 1$ & $34 \cdot 4^{10}$ & $2 \cdot 5$ & $937^{b}$ & $470 \cdot 7$ & $809^{\mathrm{b}}$ & $32 ! \cdot 8$ & $661^{\text {Ac }}$ & $166 \cdot 8$ \\
\hline 3.0 to $3.25($ no. $=8)$ & $45 \cdot 8^{b}$ & 6.9 & $36 \cdot 6^{\mathrm{b}}$ & $5 \cdot 2$ & $1018^{\mathrm{b}}$ & $339 \cdot 2$ & $622^{\mathrm{b}}$ & $232 \cdot 4$ & $923^{\mathrm{Ac}}$ & $481 \cdot 5$ \\
\hline 3.5 to $3.75($ no. $=8)$ & $54 \cdot 1^{\text {Ac }}$ & 3.9 & $43 \cdot 8^{c}$ & 3.7 & $1820^{\circ}$ & $614 \cdot 6$ & $1285^{\circ}$ & $53.5 \cdot 8$ & $1.589^{3 \mathrm{ic}}$ & $664 \cdot 3$ \\
\hline 4.0 to $4.50($ no. $=12)$ & $61 \cdot 2^{13 \mathrm{c}}$ & $7 \cdot 1$ & $52 \cdot 3^{4}$ & $6 \cdot 9$ & $3049^{d}$ & $727 \cdot 6$ & $1603^{\circ}$ & $321 \cdot 2$ & $2496^{\circ}$ & $48.4 \cdot 8$ \\
\hline
\end{tabular}

+ Means with different superscripts differ significantly at $P<0.05$ (lower case) and at $P<0.01$ (upper case). 
TABLE 2

Composition of the corrected half carcass weights grouped according to body condition score $(B C S) \dagger$

$$
\begin{aligned}
& \text { Corrected } \\
& \text { Cold carcass half carcass } \\
& \text { weight }(\mathrm{kg}) \text { weight }(\mathrm{g}) \text { Muscle }(\mathrm{g}) \text { Bone }(\mathrm{g}) \\
& \text { Kidney and Bone and } \\
& \text { SubcutaneousIntermuscular pelvic fat remainder } \\
& \text { fat }(\mathrm{g}) \quad \text { fat }(\mathrm{g}) \quad(\mathrm{g}) \\
& \text { (g) } \\
& \overbrace{\text { Mean s.d. }} \overbrace{\text { Mean s.d. }} \overbrace{\text { Mean s.d. }} \overbrace{\text { Mean s.d. }} \overbrace{\text { Mean s.d. }} \overbrace{\text { Mean s.d. }} \overbrace{\text { Mean s.d. }}^{\text {Mean s.d. }}
\end{aligned}
$$

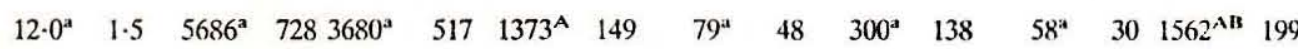

$$
\begin{aligned}
& \begin{array}{llllllllllllllll}
13 \cdot 1^{\mathrm{a}} & 1.4 & 6172^{\mathrm{a}} & 718 & 3854^{\mathrm{a}} & 505 & 1291^{\mathrm{A}} & 190 & 163^{\mathrm{b}} & 82 & 535^{\mathrm{b}} & 135 & 137^{\mathrm{b}} & 54 & 1469^{\mathrm{A}} & 208
\end{array}
\end{aligned}
$$

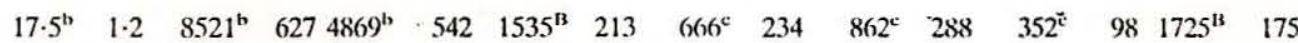

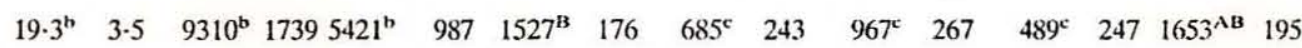

$$
\begin{aligned}
& \begin{array}{llllllllllllllll}
23 \cdot 6^{\mathrm{c}} & 2 \cdot 9 & 11465^{\mathrm{c}} & 1623 & 5945^{\mathrm{Ac}} & 737 & 1595^{\mathrm{B}} & 187 & 1489^{\mathrm{d}} & 667 & 1386^{\mathrm{d}} & 353 & 839^{\mathrm{d}} & 343 & 1719^{\mathrm{AB}} & 281
\end{array}
\end{aligned}
$$

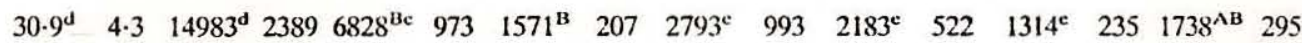

was $11.3 \mathrm{~kg}$. The data plotted in Figure 1 suggest, however, that the change in live weight per unit change in condition score is not linear. The best relationship between live weight and BCS was fitted and is shown in equation 2, Table 3 .

The correlation coefficients between fat depots and BCS are given in Table 4. All coefficients are significant $(P<0.001)$. The equations ( 3 to 9$)$ in Table 3 express these relationships and Figure 2 shows the relationship between total fat in the body and BCS. All relationships are significant $(P<0.01)$. In fact proportionately 0.90 of the variation in total fat weight was

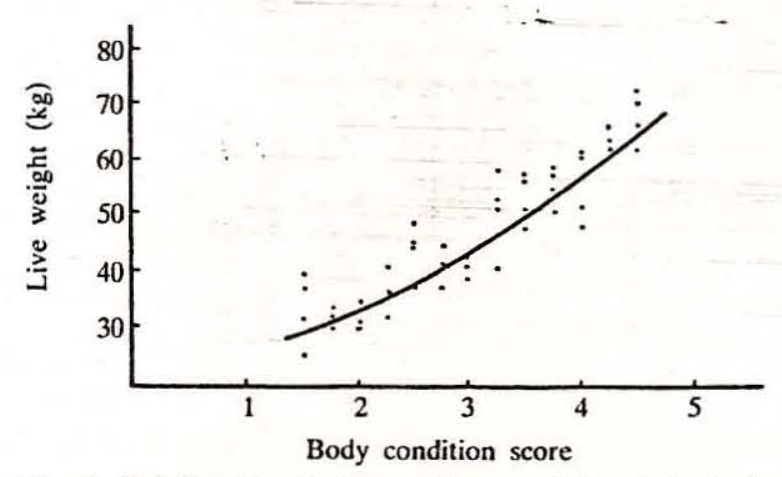

FIG. 1. Relationship between live weight and body condition score: $\log _{10}$ live weight $=0.11 \mathrm{BCS}+1.3$ $\left(r=0.91 ; s_{b}=0.007 ; s_{y x}=0.05\right)$. accounted for by variation in BCS, whereas 0.84 was accounted for by variation in live weight. In the relationships for individual fat depots, 0.86 to 0.90 of the variation in live weight accounted for 0.69 to 0.80 of the variation in the different fat depots.

The inclusion of live weight as an independent variate in a multiple regression with BCS did not improve the precision of prediction.

The partitions of fat at 'different condition scores are summarized in Figure 3. This

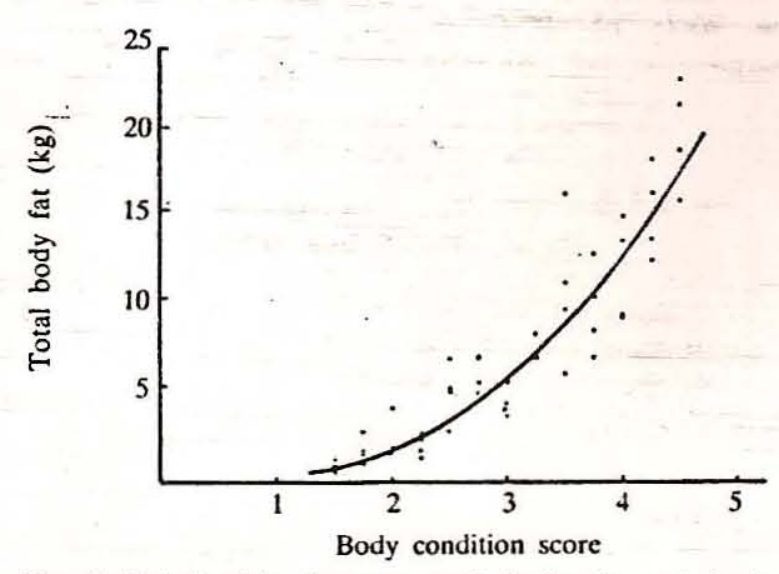

Fig. 2. Relationship between total body fat and body condition score: $\log _{10}$ total body fat $=2.66$ BCS -0.49 $\left(r=0.95 ; s_{h}=0.13 ; s_{y: k}=0.14\right)$. 
TABLE 3

Regression.relationships between live weight $(L W)$, fat depots and body condition score (BCS)

\begin{tabular}{|c|c|c|c|c|c|c|c|c|c|c|c|c|c|}
\hline \multirow{2}{*}{\multicolumn{2}{|c|}{-1}} & \multicolumn{6}{|c|}{ Linear and semilogarithmic } & \multicolumn{6}{|c|}{ Logarithmic } \\
\hline & & $a$ & $b$ & $\begin{array}{l}\text { s.e. } \\
\text { of } b\end{array}$ & $r$ & $\begin{array}{l}\text { Residual } \\
\text { s.d. }\end{array}$ & $\begin{array}{l}\text { Independent } \\
\text { variable }\end{array}$ & $a$ & $b$ & $\begin{array}{l}\text { s.e. } \\
\text { of } b\end{array}$ & $r$ & $\begin{array}{l}\text { residual } \\
\text { s.d. }\end{array}$ & $\begin{array}{l}\text { Independent } \\
\text { variable }\end{array}$ \\
\hline (1) & LW (kg) & $12 \cdot 6$ & $11 \cdot 3$ & 0.74 & 0.90 & $5 \cdot 0$ & BCS & & & & & & \\
\hline & $\log _{a 0} \mathrm{LW}(\mathrm{kg})$ & $1 \cdot 3$ & 0.11 & $10 \cdot 077$ & 0.91 & 0.05 & $\mathrm{BC}$ & & & & & & \\
\hline & $\begin{array}{l}\log _{n} \text { omental } \\
\text { fat }(\mathrm{g})\end{array}$ & $-2761 \cdot 2$ & $88 \cdot 4$ & $6 \cdot 5$ & 0.89 & $545 \cdot 9$ & LW & & & & & & \\
\hline & Omental fat (g) & & & & & & & 1.45 & 3. & $0 \cdot 17$ & 0.93 & $0 \cdot 18$ & $\mathrm{BCS}$ \\
\hline $\begin{array}{l}\text { (5) } \\
\text { (6) }\end{array}$ & $\begin{array}{l}\text { Mesenteric fat }(\mathrm{g}) \\
\text { Kidney and }\end{array}$ & $-1034 \cdot 1$ & $41 \cdot 5$ & 3.9 & 0.83 & 0.17 & LW & 1.97 & 1.91 & $0 \cdot 18$ & $0 \cdot 84$ & 0 & $\mathrm{PC}$ \\
\hline & $\begin{array}{l}\text { pelvic fat (g) } \\
\text { Subcutaneous }\end{array}$ & $-2217 \cdot 8$ & $71 \cdot 8$ & $5 \cdot 7$ & $0 \cdot 87$ & $482 \cdot 7$ & $\mathrm{~L}$ & $1 \cdot 28$ & $3 \cdot 39$ & $0 \cdot 17$ & 0.94 & $0 \cdot 17$ & $3 \mathrm{CS}$ \\
\hline & $\begin{array}{l}\text { fat (g) } \\
\text { Intermuscular }\end{array}$ & $-5 \cdot 04$ & 4.71 & $0 \cdot 36$ & $0 \cdot 88$ & $0 \cdot 29$ & $\log _{t n}$ LW & $1 \cdot 10$ & $3 \cdot 82$ & $0 \cdot 19$ & 0.94 & $0 \cdot 20$ & BCS \\
\hline & fat (g) & -1519.9 & $56 \cdot 9$ & $3 \cdot 86$ & 0.90 & 324 . & L & 2.02 & $2 \cdot($ & $0 \cdot 11$ & 0.93 & 0.1 & BCS \\
\hline & Total body fat $(\mathrm{kg})$ & $-13 \cdot 99$ & 0.46 & 60.03 & 0.92 & $2 \cdot 40$ & LW & -0.49 & $2 \cdot 66$ & $0 \cdot 13$ & $0 \cdot 95$ & $0 \cdot 14$ & BCS \\
\hline
\end{tabular}

TABLE 4

Correlation coefficients between fat depots with body condition score

(1) Mesenteric fat $\quad 0.87$

(2) Kidney and pelvic fat $0.92 \quad 0.85$

(3) Subcutaneous fat $\quad 0.89 \quad 0.83 \quad 0.86$

$\begin{array}{llllll}\text { (4) Intermuscular } & \mathbf{0 . 9 2} & \mathbf{0 . 8 4} & 0.91 & 0.95\end{array}$

$\begin{array}{llllllllll}\text { (5) Total body fat } \quad 0.93 & 0.89 & 0.91 & 0.97 & 0.95\end{array}$

(6) Body condition score $\begin{array}{llllll}0.93 & 0.84 & 0.94 & 0.94 & 0.93 & 0.95\end{array}$

OFt (1) (2) (3) (4) (5)

$\dagger \mathrm{OF}=$ Omental fat

TABLE 5

Relative growth coefficients of fat depots

\begin{tabular}{|c|c|c|c|c|c|}
\hline \multirow[b]{2}{*}{. } & \multicolumn{5}{|c|}{$\begin{array}{c}\log _{10}(\text { fat depot }) \\
=a+b \log _{10}(\text { total body fat })\end{array}$} \\
\hline & $a$ & $b$ & s.e. of & $r^{2}$ & $S_{y, x}$ \\
\hline Omental fat & -1.53 & $1 \cdot 19^{\mathrm{aA}}$ & 0.04 & 0.96 & $0 \cdot 11$ \\
\hline Mesenteric fat & 0.08 & $0.74^{\mathrm{b}}$ & 0.04 & $0 \cdot 85$ & $0 \cdot 13$ \\
\hline Kidney and pelvic fat & -1.82 & $1 \cdot 25^{\mathrm{aB}}$ & 0.04 & 0.95 & $0 \cdot 12$ \\
\hline Subcutaneous fat & -2.21 & $1.42^{\mathrm{c}}$ & 0.04 & 0.97 & $0 \cdot 11$ \\
\hline Intermuscular fat & 0.42 & $0 \cdot 76^{b}$ & $0 \cdot 02$ & $0 \cdot 96$ & $0 \cdot 07$ \\
\hline
\end{tabular}

shows that the higher proportions of total fat in $\mathrm{BCS}$ from 1.5 to 2.5 are the intermuscular and mesenteric fats, while in BCS higher than 3.5 , the subcutaneous, intermuscular and omental fats are the main fat depots represented in total body fat. The kidney and pelvic fat start to be important at scores higher than $2 \cdot 5$.

Table 5 shows the values for the coefficients $a$ and $b$ from the equation of Huxley (1932). The fat deposition order in adult ewes, with live weights between 32 and $67 \mathrm{~kg}$ and BCS from 1.5 to 4.5 is: mesenteric, intermuscular, omental, kidney and pelvic and subcutaneous fat.

The regression equations between individual fat depots and the tail fatness score and BCS are presented in Tables 6 and 7. Of the variation in the weight of the individual fat depots, proportionately 0.79 to 0.86 was accounted for by variation in tail fatness

TABLE 6

Regression equations between individual fat depots and the tail fatness score

Omental fat

Mesenteric fat

Kidney and pelvic fat

Subcutaneous fat

Intermuscular fat

Total body fat $\log _{10}$ (fat depot) $=a+b$ (tail fatness score)

\begin{tabular}{ccccc}
\hline \multicolumn{5}{c}{ s.e. of } \\
$a$ & $b \dagger$ & $b$ & $r$ & $S_{y x}$ \\
1.2 & 0.18 & 0.01 & 0.91 & 0.21 \\
2.2 & 0.11 & 0.01 & 0.84 & 0.18 \\
1.7 & 0.19 & 0.01 & 0.89 & 0.24 \\
1.5 & 0.22 & 0.01 & 0.93 & 0.22 \\
2.3 & 0.12 & 0.01 & 0.90 & 0.14 \\
-0.01 & 0.15 & 0.01 & 0.92 & 0.16
\end{tabular}




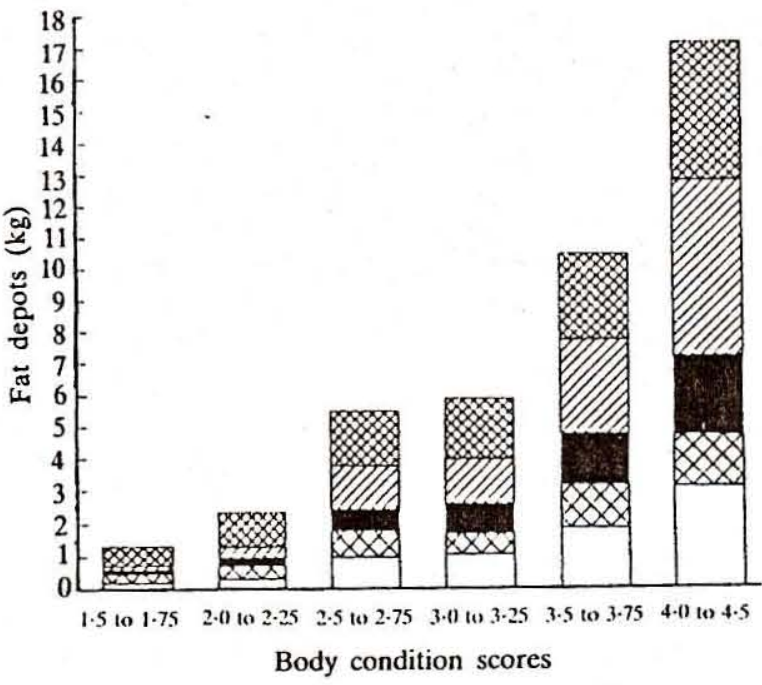

F1G. 3. Fat partition at different body condition scores: intermuscular fat; $\mathbb{Z}$ subcutaneous fat; kidney knob and channel fat; $\triangle$ mesenteric fat: $\square$ omental fat.

TABLE 7

Regression equations between individual fat depots and body condition score (BCS)

\begin{tabular}{|c|c|c|c|c|c|}
\hline & \multicolumn{5}{|c|}{$\begin{aligned} & \log _{10}(\text { fat depot) } \\
= & a+b \log _{10}(\mathrm{BCS})\end{aligned}$} \\
\hline & $a$ & $b$ & s.e. of & $r$ & $S_{y x}$ \\
\hline Omental fat & 1.45 & $3 \cdot 2$ & $0 \cdot 17$ & 0.93 & $0 \cdot 18$ \\
\hline Mesenteric fat & 1.97 & $1 \cdot 9$ & $0 \cdot 18$ & $0 \cdot 84$ & $0 \cdot 17$ \\
\hline Kidney and pelvic fat & $1-28$ & 3.4 & 0.17 & 0.94 & $0 \cdot 17$ \\
\hline Subcutaneous fat & 1.01 & $3 \cdot 8$ & 0.19 & 0.94 & $0 \cdot 20$ \\
\hline Intermuscular fat & $2 \cdot 02$ & $2 \cdot 1$ & $0 \cdot 11$ & 0.93 & $0 \cdot 12$ \\
\hline Total body fat & $-0 \cdot 49$ & $2 \cdot 7$ & $0 \cdot 13$ & 0.95 & $0 \cdot 14$ \\
\hline
\end{tabular}

score while the variation in BCS accounted for 0.86 to 0.90 of those variations.

The change in live weight per unit change in condition score derived from equation 1 in Table 3 is $11.3 \mathrm{~kg}$; very similar to the $10.56 \mathrm{~kg}$ found by Russel et al. (1969) for Scottish Blackface ewes. The semilogarithmic equation 2 in Table 3 , between live weight and BCS shows, however, that live weight increased by $8.4,11.0$ and $14.0 \mathrm{~kg}$ when BCS increased from 1.5 to $2.5,2.5$ to 3.5 and 3.5 to 4.5 respectively.

The results from regression analysis show that BCS was a better predictor than live weight of the weight of total body fat; this agrees with the results of Russel et al. (1969); Milligan and Broadbent (1974) and Paramio and Folch (1985). BCS is also a better predictor of the weight of individual fat depots than live weight. Table $\dot{8}$ shows the changes in the weight of fat depots per unit change in BCS, calculated from equations 3 to 8 in Table 3 . These changes suggest that intermuscular fat would be the first depot to be mobilized during reduction of body condition from 2 to 1 while increases in condition score from 3 to 4 or from 4 to 5 would result in the greatest rate of deposition occurring in the subcutancous and omental depots.

From Figure 3, it is evident that in condition scores 1.5 to 2.5 the intermuscular and mesenteric fats have a higher proportion of total body fat. This suggests that the intermuscular and mesenteric fat in the Aragonesa breed, when the condition score ranges between 1.5 to 2.5 , could be assessed individually by palpation.

The relative growth coefficients for all fat depots, indicate that as the total body fat increased the proportion of subcutaneous, kidney and pelvic, and omental fat increased and the proportion of intermuscular and mesenteric fat decreased. There were no significant differences between mesenteric and intermuscular fat deposition. These results are in agreement with physiological principles of growth and fat deposition (Hammond, 1932).

The late deposition of subcutaneous fat found in the ewes in this study has also been reported by Russel, Gunn, Skedd and Doney (1968) and Russel, Doney and Gunn (1971). Deposition of subcutaneous fat after TABLE 8

Change in weight of fat depots per unit change in body condition score (BCS)

Change in BCS

\begin{tabular}{cccc}
\hline 1 to 2 & 2 to 3 & 3 to 4 & 4 to 5 \\
231 & 689 & 1432 & 2481 \\
258 & 462 & 505 & 701 \\
181 & 590 & 1304 & 2368 \\
270 & 1070 & 1272 & 5492 \\
652 & 1108 & 1572 & 2042 \\
1.7 & 4.0 & 6.3 & 11.1
\end{tabular}


intermuscular fat has also been demonstrated in lambs (e.g. Thompson. Atkins and Gilmour, 1979; Kempster, 1980).

These resuits suggest ibat the kidney and pelvic depots are earlier developing than the subcutaneous depot but later than intermuscular fat, which again agrees with Kempster (1980). Nevertheless Butler-Hogg (1982) reported that kidney and pelvic was biphasic in development. Kempster (1980) showed that the growth of kidney and pelvic fat relative to the other fat depots can vary. This variation in results could however be due to breed clifferences which have been demonstrated by Donald, Read and Russell (1970); McClelland and Russel (1972); Kempster and Cuthbertson (1977) and Kempster, Croston and Jones (1987). The partition and relative growth of fat should therefore be determined for each breed.

The BCS is a better predictor than tail fatness of the weight of individual fat depots nevertheless the tail fatness score could be used as an additional method of assessing body condition in Aragonesa breed when the range in body condition is wide.

\section{ACKNOWLEDGEMENTS}

This work has been supported by DGA, INIA and IAMZ. The authors gratefully acknowledge to DR Timothy Treacher from Institute of Grassland and Animal Production and to Dr Norman Casey from Pretoria University, for their helpful advice during the progress of this work and for the revision of the manuscript.

\section{- REFERÉNCES}

Butlfr-Hogg, B. W. 1982. Fat partitioning in Clun and Southdown lambs. Animal Production 34: 377 (Abstr.).

Donald, H. P., Rean, J. L. and Russele, W. S. 1970. Influence of litter size and breed of sire on carcass weight and quality of lambs. Animal Production 12: 281-290.

Gunn, R. G., Doner. J. M. and Russri, A. J. F. 1969. Fertility in Scottish Blackface ewes as influenced by nutrition and body condition at mating. Journal of Agriculural Science, Cumbridge 73: 289-294.

GunN, R. G., DONFY, J. M. and Russt:L, A. J. F. 1972. Embryo mortality in Scottish Blackface ewes as influenced by body condition at mating and post-mating nutrition. Journal of Agricultural Science, Cambridge 79: $19-25$.
Gunv, R. G., Dontr. J. N. and Swrm, W. F. 1979). Fertility in Cheviot eswes. 2. The effect of ieves of pre-mating nutrition on atation ratc and early embryo mortality in North and South Country Cheviot ewes in moderately good conditun at mating. Anumal Production 29: 17-23.

HAMmond, J. 1932. Growth and tine Deveiofment of Muton Qualities in the Sherep. 2nd ed. Oliver and Boyd, Edinburgh.

Huxery, J. S. 1932. Problems of Relaive (irowth, p. 276. Methuen, London.

JeFrertes, B. C. 1961. Body condition scoring and its use in management. Tasmunian Journal of Agriculare 32: $19-21$.

Kempstr:R, A. J. 1980. Fat partition and distribution in the carcass of cattle, sheep and pigs: a review. Meat Science 5: 83-98.

Kempsti:r, A. J., Croston, D. and Jonis, D. W. 1987. Tissue growth and development in crossbreed lambs sired by ten breeds. Livestock Production Science 16: $145-162$.

Kempstir, A. J. and Cummurtson, A. 1977. A survey of the carcass characteristics of the main types of British lamb. Animal Production 25: 165-179.

MCClelland, T. H. and Russiti, A. J. F. 1972. The distribution of body fat in Scottish Blackface and Finnish Landrace lambs. Animal Production 15: 301-306.

Mitltgin, K. E. and Brombuint, J. S. 1974. Condition scoring of sheep. Proceedings of the New Zealand Society of Animal Production 34: 114 (Abstr.).

Murray, J. A. 1919. Meat production. Journal of Agricultural Science, Cambridge 9: 174-181.

Paramio, M. T. and Folch, J. 1985. Puntuación de la condición corporal en la oveja Rasa Aragonesa y su relación con las reservas energéticas y los parametros reproductivos. Informacion Técnica Económica Agravia 58: $29-44$.

Russi:t., A. J. F., Doni:y, J. M. and Gunn, R. G. 1969. Subjective assessment of body fat in live sheen. Journal of Agricultural Science. Cambridge 72: $451-454$.

Russi:L, A. J. F., DONEY, J. M. and GUNN, R. G. 1971. The distribution of chemical fat in the bodies of Scottish Blackface ewes. Animai Production 31: 503-509.

Russel, A. J. F., Gunn, R. G., Skrim), E. and Doney, J. M. 1968. Relationships between chemical and physical composition of Scottish Blackface ewes. Animal Production 10: 53-58.

Steel, R. G. D. and Torki上, J. H. 1980. Principles and Procedures of Statistics. 2nd ed. McGraw-Hill. New York.

Thompson, J. M., Atkins, K. D. and Gilmour, A. R. 1979. Carcass characteristics of heavyweight crossbred lambs. II. Carcass composition and partitioning of fat. Australian Journal of Agricultural Research 30: 1207-1214.

(Received 4 March 1988-Accepted 12 May 1989)

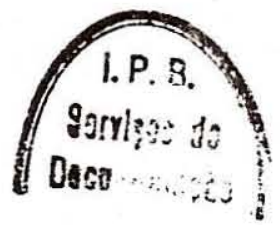

